should make increasing use of the universities for research. In replying to the debate, Mr. G. R. H. Nugent, the Parliamentary Secretary to the Ministry of Agriculture, Fisheries and Food, admitted the need for such long-term planning, but pointed out that an annual Vote would be needed, even with a quinquennial programme. He thought the arrangements for disseminating the results of research are working well, and, in reply to questions as to a veterinary research council, said that this had been considered by the Lord President but was thought to offer no advantage at the present time. Eleven of the sixteen experimental farms and six out of seven horticultural experimental farms have been established.

British Section of the International Union for the Study of Social Insects

A NuMBER of entomologists present in Amsterdam at the ninth International Congress of Entomology in 1951 felt that an organization should be formed to bring together those scientists who were engaged in studying the physiology, biology or systematics of the social insects. Thus the Union Internationale pour l'Étude des Insectes Sociaux was initiated, under the presidency of Prof. P.-P. Grassé. The purpose of the Union has since been expanded to include researches on gregarious insects. A Congress was held in Paris in 1952, followed by a highly successful one at Würzburg earlier this year ; the next Congress, in 1957, will again be held in Paris. The international journal Insectes Sociaux, published in Paris, is completing its second volume. National Sections have been formed in many countries, but until recently British workers in this field have been members of the French Section; however, a British Section has now been formed under the chairmanship of Dr. J. D. Carthy. The subscription to the Section is $10 \mathrm{~s}$. a year, which includes membership of the International Union, and the Union supplies members with lists of current papers on the subject and notes concerning the activities of the Union as a whole. The cost of Insectes Sociaux is 2,000 francs a year for members and 3,000 francs for non-members. The honorary secretary of the new Section is Dr. C. G. Butler, of the Bee Department, Rothamsted Lodge, Hatching Green, Harpenden, Herts, from whom further information can be obtained.

\section{The Breeding of Laboratory Animals}

IN the past, experiments on animals were usually done in qualitative terms. To-day biological research has become quantitative in character, and with this approach it is becoming evident that healthy, vigorous and uniform stock is essential for controlled experimental studies and for assaying drugs and other therapeutic agents not susceptible to chemical standardization. What is needed are standardized animals or ones nearly so; Mr. A. L. Bacharach suggests that a standardized animal is to the biologist what a pure reagont is to the chemist. The way in which these animals might be bred was described at a symposium organized by the Laboratory Animals Bureau on May 9, 1955. The subjects discussed included some aspects of animal production for routine biological assay; genetical aspects of the breeding of laboratory animals; the value of littermate controls in endocrinological research ; pre-natal and post-natal reproductive wastage; and the problems of a curator of a small animal breeding station at a university. The papers, and some of the ensuing discussion, have now been put together in book form and can be obtained from the Laboratory Animals Bureau, Medical Research Council Lab. oratories, Holly Hill, Hampstead, London, N.W.3 (7s. 6d.).

\section{Linen Research Association: Annual Report}

IN proposing the adoption of the report of the Council of the Linen Research Association and the accounts at the annual general meeting of the Association on December 16, the chairman, Mr. H. B. McCance, said that the trade subscriptions now amount to $£ 32,385$ compared with $£ 7,033$ in 1939, and the floor space of the Institute has been increased from 33,408 sq. ft. to $45,837 \mathrm{sq}$. $\mathrm{ft}$. In seconding the motion, Mr. M. Wallace expressed the opinion that any fundamental change in the basic methods of preparing and spinning flax is unlikely, but that the servo-drafting control mechanism is an example of how new control methods can be applied to improve an old process. The director of research, Dr. A. J. Turner, in his report, instanced the reduction of lick-up on the rollers of preparing frames by simultaneous application of a number of auxiliary devices, as an example of the real progress being made towards the solution of obstinate spinning problems. In the Weaving Department attention has been concentrated on the improvement of the preparatory processes, while in the Chemistry Department much further experience has been obtained of synthetic resin finishes and promising results obtained in applying new synthetic compounds in waterproofing flax canvasses. After stressing the new opportunities for research and the importance of maintaining a scientific staff of bigh calibre, Dr. Turner said that the Institute's studies of the processing of such fibres as acetate rayon, nylon, 'Terylene' and 'Orlon' have already accumu. lated a considerable store of knowledge on these fibres, individually and in blends; he expressed the belief that man-made fibres could be introduced with advantage into the textile economy of Northern Ireland and that the dry-spinning industry in Scotland would likewise benefit from these investigations.

\section{Peaceful Uses of Atomic Energy}

THE Association of Scientific Workers and the Labour Research Department have produced a useful pamphlet on the "Peaceful Uses of Atomic Energy" (pp. 16; 1955; from the Association; 6d.), which is designed to give the ordinary citizen a clear idea of the nature of nuclear science and the nature and possibilities of nuclear power, particularly for Britain, including the uses of radioactive materials. The pamphlet is simpler and much shorter than that of the Central Office of Information on "Nuclear Development" or the White Paper "A Programme of Nuclear Power". Though the pamphlet does less than justice to British developments with radioactive isotopes, it can be commended as likely to assist the general understanding of potentialities in this field. Little is said of the demand its development may make on our resources of materials or of scientific man-power.

\section{Chemistry of Colouring Matters: Symposium in London}

A symposium on "Recent Advances in the Chem. istry of Colouring Matters" has been arranged by the Chemical Society and will be held in the Royal Institution, Albemarle Street, London, W.1, during 